\title{
Air temperature trends and extremes in Chisinau (Moldova) as evidence of climate change
}

\author{
Roman Corobov $^{1, *}$, Scott Sheridan ${ }^{3}$, Ala Overcenco ${ }^{2}$, Natalia Terinte $^{4}$ \\ ${ }^{1}$ CRDF Project MOB-2928-CS-08, and ${ }^{2}$ National Center for Public Health, 67a Gh. Asachi str., 2028 Chişinău, \\ Republic of Moldova \\ ${ }^{3}$ Department of Geography, Kent State University, Kent, Ohio 44242, USA \\ ${ }^{4}$ Meteorological Department of MoldATSA, Box 989, 2026 Chişinău, Republic of Moldova
}

\begin{abstract}
A trend analysis of surface temperature in Chisinau (Moldova) between 1887 and 2008 is presented. The observational data included monthly mean temperatures (Tmean) for the whole period, and monthly mean maximum (Tmax) and minimum (Tmin) temperatures since 1945. The following principal aspects were studied: (1) long-term temperature trends and changes in their patterns; (2) seasonal temperature extremes and their links with rising mean temperatures; and (3) an extremely hot summer of 2007 in Moldova as evidence of regional warming. In the last 3 decades, strong positive trends were observed in all temperature variables and, unlike previous periods (1945-1980), have become statistically significant for most seasons. Trends increased drastically: annual, winter and summer Tmean rose by about $0.62,0.50$ and $0.95^{\circ} \mathrm{C}$ per decade, respectively, in 1981-2008, compared with $0.035,0.075$ and $0.018^{\circ} \mathrm{C}$ per decade, respectively, in 1887-1980. Means of seasonal (except autumn) and annual temperatures in 1981-2008 differed from previous years at a 95\% and higher confidence level; their variability, expressed in standard deviation (SD) values $(\sigma)$, did not change significantly. In the last 3 decades there was practically no significant change in means, variability and distribution of Tmax in comparison with 1945-1980; however, Tmin changed significantly in all these statistics. The lack of significant changes in recent Tmax resulted in a relative stability of the frequency of temperature extremes, defined as the 90th and 95th percentiles of long-term distributions in winter and summer; some increase is observed only for absolute maxima. In 1981-2008 these thresholds for mean Tmin were exceeded 7 and 3 times, respectively, compared to the 1940s-1970s, when there were no such extreme events. The results strongly suggest that the observed warming in Chisinau was primarily caused by the Tmin increase. In summer 2007, monthly Tmean exceeded the corresponding values of the baseline (1961-1990) climate by $2.5-4.0 \sigma$, the seasonal Tmean by $5 \sigma$.
\end{abstract}

KEY WORDS: Climate change $\cdot$ Air temperature trends $\cdot$ Extremes $\cdot$ Moldova

\section{INTRODUCTION}

The Earth's climate is changing (Jones et al. 2009), resulting in numerous negative consequences and crating challenges for policymakers, scientists and the general public (IPCC 2007a,b). The principal conclusion of the Fourth Assessment Report of the Intergovernmental Panel on Climate Change (IPCC AR4) was that the 'warming of the climate system is unequivocal, as is now evident from observations of increases in global average air and ocean temperatures, widespread melting of snow and ice, and rising global aver- age sea level' (IPCC 2007a, p. 5). The notion that climate change may alter the mean, variability and extremes of relevant weather variables is now widely accepted, resulting in increased attention to research in these areas over recent decades (Albert et al. 2009). The primary goal of many studies has been to assess global warming at a regional level (e.g. Groisman \& Ivanov 2008) and to estimate empirical links between increased air temperatures and the frequency of extreme events (Beniston \& Stephenson 2004, Good et al. 2006, Tebaldi et al. 2006, Semenov 2008, Albert et al. 2009). Air temperature trends differ from their 
global patterns at a continental scale (Gil-Alana 2008); they differ even more at a regional scale (e.g. Lu et al. 2004, Corobov 2008). Further, to facilitate adaptation to a changing climate, stakeholders are often interested not only in the magnitude of a temperature trend, but also in possible changes in temperature variability.

Climate extremes affect all sectors of national economies-agriculture, water resources, industry, transportation and human health. Observational evidence and model simulations show that appreciable changes in the variability and long-term trends of extreme events are very likely in a gradually warming world (Benestad 2003, Beniston et al. 2005, 2007, Unkaśević et al. 2005, Tebaldi et al. 2006, Semenov 2008). In this case, the dynamic of extremes is an important indicator of global warming, and the knowledge of their nature can strengthen the preparedness of society for anticipated changes in weather patterns and climate perturbations.

The impact of climate extremes can be severe and wide ranging; however, the most dramatic effects will be at local and regional scales (Adger et al. 2005, Good et al. 2006, Therivel \& Ross 2007). Much work has been done on this subject, especially in special European projects (e.g. STARDEX and MICE, see Appendix 1 for details), conferences, workshops (e.g. Meehl et al. $2000 a, b)$ and numerous research studies. For example, based on the study of high temperatures in France, Parey et al. (2007) proposed a detailed methodology to identify and estimate trends in a series of very high temperatures that allows empirical laws to be formulated based on the distribution and evolution of temperature extremes with time. Information on climate extremes allows the evaluation of ongoing or recent events placed in an historical context. But whereas in an extreme value analysis it is possible to account for nonstationary conditions such as trends, there is still debate about the best way to do this (Albert et al. 2009).

In this paper, we present the results of 3 research goals: (1) an analysis of long-term temperature trends and variability in Moldova's climate; (2) the relationship between seasonal temperature extremes and increasing mean temperatures; and (3) an assessment of the extremely hot summer of 2007 in Moldova as evidence of regional warming.

\section{METHODS}

The analysis of long-term trends in climatic variables and, moreover, in extreme events, which are rare by definition, requires as long a time series as possible to aid in the modelling of extremes; ideally, the observations should extend backwards into at least the 19th century (Benestad 2004). Therefore, in this study we analyzed air temperature records from the weather station in Chisinau, which had the longest and most reliable series of instrumental observations in Moldova. This series included the monthly mean temperatures (Tmean) for the $122 \mathrm{yr}$ period of $1887-2008$, and mean monthly maximum and minimum temperatures (Tmax and Tmin, respectively) since 1945. Over the observation period this station has changed location only once (in 1945), after a 4 yr break in observations (1941-1944) during the Second World War. Despite the station's move, the Moldova Hydrometeorological Service (MHS) considers the record as homogeneous (MHS pers. comm.). Further, there are no other long-record stations in the vicinity to serve as references in a standard homogeneity test. Presently, the Chisinau weather station is located on the outskirts of the city at one of the highest points, which practically excludes any heat-island effect. This station is included in the list of observing stations of the World Meteorological Organization (WMO), and its data are archived at the regime-reference databank of the World Data Center. Because of the small size of Moldova $\left(33846 \mathrm{~km}^{2}\right)$, the relatively homogeneous terrain, and the location of Chisinau near its geographic centre (Fig. 1), the research results could be considered as representative of the whole country. Global and northern

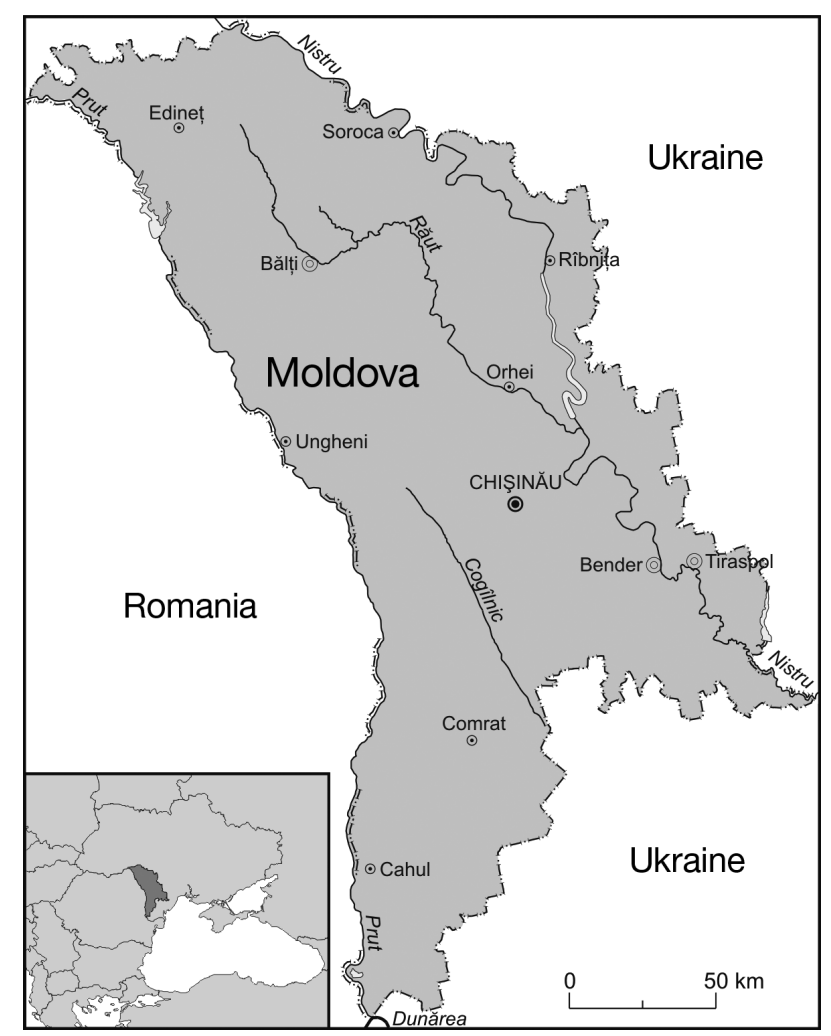

Fig. 1. Moldova, with location of Chisinau station 
hemispheric anomalies (HadCRUT3 data set) were obtained from the Climatic Research Unit of the University of East Anglia (CRU UEA),UK, website (available at: www.cru.uea.ac.uk/cru/info/warming/).

Because the early 1980s are usually taken as the breakpoint, after which anthropogenic influence on the atmosphere was reflected more prominently in the climate record (IPCC 2007a), we evaluated temperature trends for 2 periods: 1887-1980 (with 2 subperiods of 1887-1940 and 1945-1980), and 1981-2008. The year 1981, a priori selected for our research, is the same as the last year (1981) in the second subsample of Gil-Alana (2008), who estimated the breaks in global and hemispheric temperature long-term time series using a technique based on segmented trends and fractional integration. The other breakpoint of 19401945 coincides with the availability of maximum and minimum temperature records, and the interruption of observations by the Second World War.

The climate of Moldova is temperate continental (Fig. 2), slightly modified by the proximity of the Black Sea and the intrusion of warm humid air from the Mediterranean Sea. Climatic seasons are clearly defined with a short low-snow winter and a long summer, sometimes very hot and dry (Goscommet USSR 1990).

The significance of changes in temperature from 1981-2008 compared with previous years was tested through a statistical comparison of the corresponding mean and standard deviation $\left(\mathrm{SD}_{;} \sigma\right)$ values. In essence, this procedure examines the stationarity of the observation series. A stationary temporal process presupposes that its probability distribution does not change over time. The selected subsamples were compared by applying the $t$-test for means and $F$-test for variances. A more detailed comparison was made with the Kolmogorov-Smirnov (K-S) test for distributions (Statgraphics 2009).

Aside from trends over time, we also analyzed the occurrence of extreme events. The term 'extreme event' can refer to any number of weather and climate variables, described by different parameters and indexes

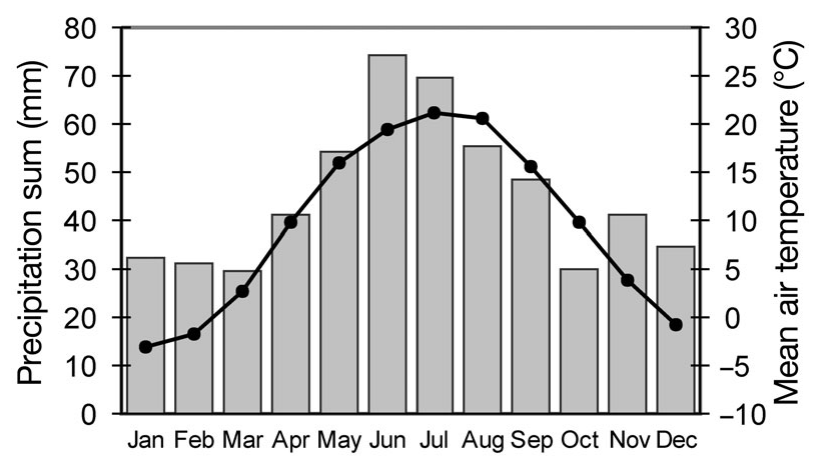

Fig. 2. Average monthly precipitation (bars) and monthly mean air temperature (curve) in Moldova from January to December (e.g. Carter et al. 2007, Albert et al. 2009). Usually, the extremes reflect rare and high impact events that occur clearly within the tail of a statistical distribution. The IPCC Glossary (IPCC 2007b, p. 875) defines an extreme weather event as 'an event that is rare within its statistical reference distribution at a particular place. Criteria of 'rarity' vary from place to place and are normally calculated as rare as (or rarer than) 10th or 90th percentile value'. As a result, many extreme temperature studies analyze the statistical behaviour of the tail of a temperature variable's probability distribution. Other research (e.g. Sillmann \& Roeckner 2008, Caprio et al. 2009) are focused on nonparametric approaches. According to Beniston \& Stephenson (2004), an attempt to relate rare or intense events to changes in mean climatic conditions is by no means trivial, and the causal relationships between isolated events and long-term trends are difficult to establish in any statistically meaningful manner.

As a generalization, there is Extreme Value Theory (Coles 2001, Parey et al. 2007, Albert et al. 2009, Suarez 2009) that relies on 2 general approaches to extreme events. (1) Those that can be considered as maxima of given blocks of time (e.g. a year or month) are described by the generalized extreme value (GEV) distribution that is a family of continuous probability distributions developed within Extreme Value Theory to combine the Gumbel, Frechet and Weibull families. The GEV distribution is the limit distribution of properly normalized maxima of a long (finite) sequence of independent and identically distributed random variables and as such is used as an approximation for the modelling of these maxima. (2) The other specification consists of the Peaks over Threshold (POT) approach where extremes are retained values over a properly chosen high threshold. In POT the series of occurrences of these events is usually the trajectory of a Poisson process. Indirectly, our work is based on these 2 considerations. The extreme temperatures were primarily computed as different tail percentiles of annual and seasonal maximum and minimum temperature distributions.

All statistical analyses were carried out with Statgraphics Centurion Data Analysis and Statistical Software (Statgraphics 2009).

\section{RESULTS AND DISCUSSION}

\subsection{Comparison with trends on larger spatial scales}

The practice of environmental management increasingly recognizes the importance of scale and crossscale dynamics in understanding and addressing global challenges. Regarding climate change, this is especially crucial, as these changes may be global in origin, yet 
are manifested regionally and locally (IPCC 2007a). Good et al. (2006, p. 20) defined the term 'pattern scaling' as '... a few experiments with complex climate models to estimate (often linear) relationships between a scalar predictor (e.g. global mean temperature) and the local quantity of interest (the predictant, e.g. annual mean temperature). These relationships are assumed to be robust such that given any value of the scalar predictor, a value of the predictant may be estimated for each location'. We used this concept to correlate the temperature series in Chisinau (expressed as anomalies from the baseline climate) with the global and northern hemispheric anomalies (Fig. 3).

While the directional trend of global temperatures is broadly reflected in Moldova, it is evident that the overwhelming part of regional climate variability is locally specific. So, the clear interruptions of Chisinau's general warming trend during the last century by interim warmer or colder temperature periods are not always 'in phase' with deviations in large-scale trends. The simple correlation (r) between global and regional anomalies is $0.405(\mathrm{p}<0.001)$. Thus, from the coefficient of determination $\left(\mathrm{r}^{2}\right)$, global climatic processes explain only $16.4 \%$ of air temperature variability in Moldova. For a comparison with Northern Hemisphere temperatures these values are $0.457(\mathrm{p}<0.001)$ and $20.1 \%$, respectively. Moreover, it appears that temperature trends are modified in Chisinau compared with global and hemisphere means, supporting the IPCC (2007a) conclusion that on a regional scale many factors other than anthropogenic ones, such as variation in atmospheric circulation and topography, may influence change in climate.

\subsection{Observed trends and variability}

As one can see from Fig. 4 and Table 1, from $1887-$ 1940 nonsignificant decreases of Tmean were ob-

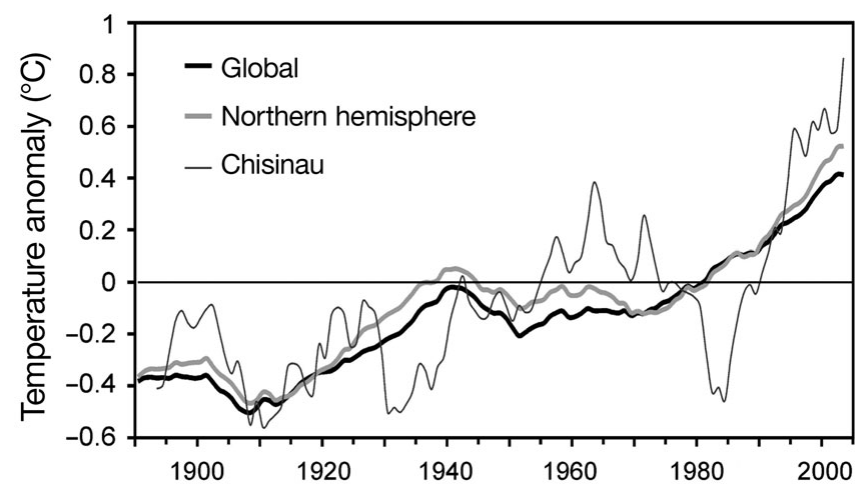

Fig. 3. Anomalies (from baseline 1961-1990 climate: zero line) of global, Northern Hemisphere and Chisinau annual air temperatures, smoothed with $11 \mathrm{yr}$ running means served in Chisinau in all seasons except summer when the trend was nonsignificantly positive. From 19451980, the annual decrease continued with a statistically significant decrease in summer temperature and nonsignificant positive trends in autumn and winter temperatures. Since 1981, all trends were positive at $\mathrm{p}<0.05$ for annual and summer temperatures, and $\mathrm{p}<$ 0.10 for spring temperature. Trends of winter and autumn Tmean in this period were not statistically significant. Thus, for the entire period of instrumental observations in Chisinau the general positive trend of Tmean was mainly determined by climate warming in the last 3 decades.

The sharp changes between 2 periods are observed for Tmax (Table 1). During 1945-1980 the temperature trend was negative in all seasons; since 1980 it has been positive, with statistically significant changes in summer, autumn and for the year as a whole. In contrast, an upward trend in minimum (night) temperatures was observed before the 1980s. Initially, it was significant only for annual $(\mathrm{p}<0.10)$ and autumn $(\mathrm{p}<$ 0.05 ) minima, but was followed by a sharp increase in later years.

An increase in the rate of trend can also be observed. During 1887-1980, the annual Tmean trend was upwards at $0.035^{\circ} \mathrm{C}_{\text {decade }}{ }^{-1}$; since 1981 it has been about $0.6^{\circ} \mathrm{C}$ eecade $^{-1}$ (Table 1 ). The equivalent trends for winter and summer were 0.5 and $0.95^{\circ} \mathrm{C}$ decade ${ }^{-1}$, respectively, from 1981 to 2008, compared with 0.075 and $0.018^{\circ} \mathrm{C}$ decade $^{-1}$ in the previous period. Moreover, $8 \mathrm{yr}$ in the last 2 decades are among the warmest $20 \mathrm{yr}$ in the history of instrumental observations in Chisinau. The significance of changes in temperature from 1981 to 2008 against previous years is shown in Tables 2 and 3.

Different research and simulations suggest that both mean and variance are likely to change with a change in climate, and their relative contribution to a new temperature regime depends on how much each statistic changes (e.g. Meehl et al. 2000b). In our case, in the last 3 decades, the seasonal (except autumn) and annual Tmean are different with high confidence from previous years (Table 2). The variance of air temperature remains (statistically) the same, thus supporting the suggestion of Meehl et al. (2000b, p 430) that 'the change in the mean is usually larger than the change in variance for most climate change simulations'. The synergetic effect of change in means and variability results in a distribution change. Thus, results suggest that over the last 3 decades Chisinau has had a new mean climate (at the significance level of $10 \%$ and less), in comparison with the previous long-term period, for all seasons except autumn ( $p$ 0.5). However, when the most recent decades are compared with 1945-1980, there are only significant 
Mean
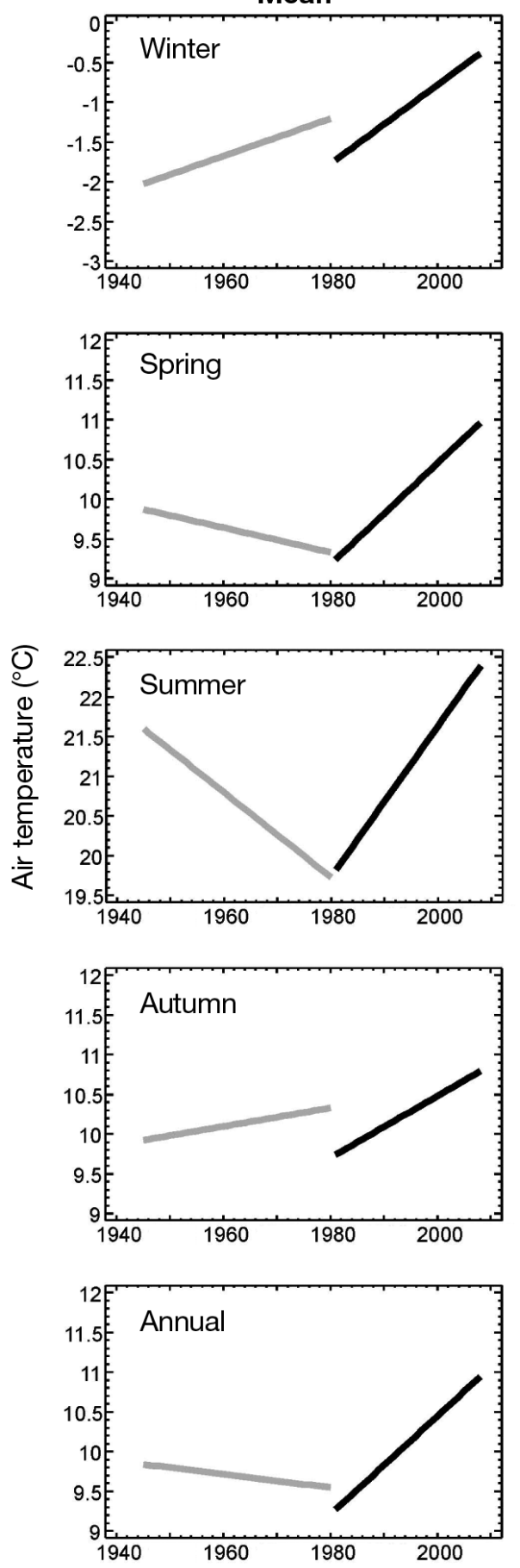

Maximum
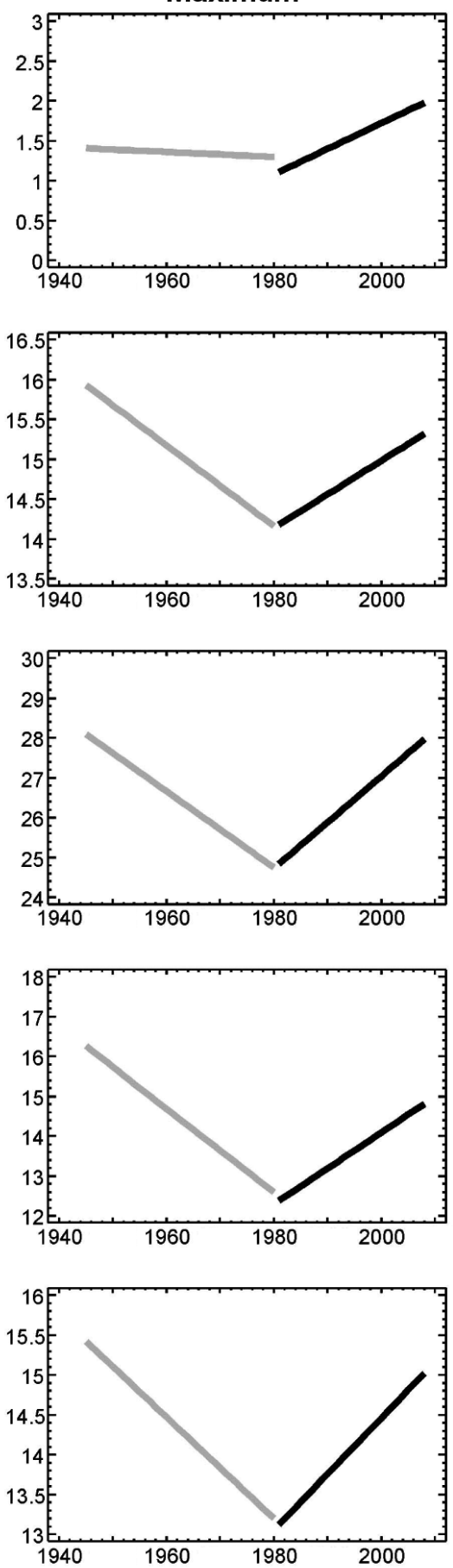

Minimum
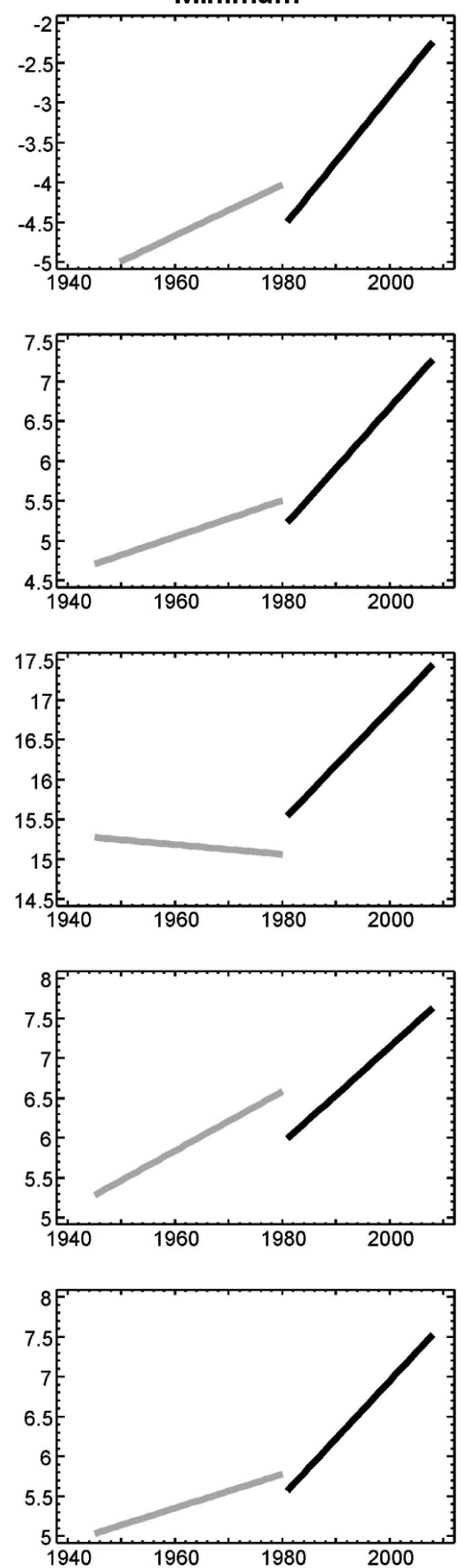

Fig. 4. Comparisons of air temperature trends for the periods of 1945-1980 (grey) and 1981-2008 (black) at Chisinau

differences in the distribution of Tmean at the annual level (Table 2).

Our research also supports the results of other research (IPCC 2007a,b) in detecting an asymmetry between the change in maximum and minimum temperatures. There are practically no significant differences between 3 statistics of maximum seasonal temperatures in the present climate in comparison with the 1940s1970s (Table 3). However, Tmin changed significantly, in terms of its mean, the variability of annual values and in its distribution, at $\mathrm{p}<0.05$ in all seasons except winter $(p=0.132)$. Thus, one can conclude that in the last 3 decades the observed general warming of Chisinau is caused primarily by an increase of minimum temperatures. 


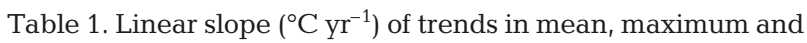
minimum air temperature (Tmean, Tmax and Tmin, respectively) and their statistical significance (p) for several different time periods of observations

\begin{tabular}{|c|c|c|c|}
\hline & & Slope & $\mathrm{p}$ \\
\hline \multicolumn{4}{|l|}{ Tmean } \\
\hline \multirow[t]{5}{*}{ 1887-1940 } & Winter & -0.0062 & 0.718 \\
\hline & Spring & -0.0033 & 0.768 \\
\hline & Summer & 0.0021 & 0.815 \\
\hline & Autumn & -0.0005 & 0.974 \\
\hline & Year & -0.0020 & 0.761 \\
\hline \multirow[t]{5}{*}{ 1945-1980 } & Winter & 0.0234 & 0.519 \\
\hline & Spring & -0.0155 & 0.541 \\
\hline & Summer & -0.0534 & 0.003 \\
\hline & Autumn & 0.0116 & 0.517 \\
\hline & Year & -0.0084 & 0.531 \\
\hline \multirow[t]{5}{*}{ 1887-1980 } & Winter & 0.0075 & 0.487 \\
\hline & Spring & 0.0001 & 0.991 \\
\hline & Summer & 0.0018 & 0.687 \\
\hline & Autumn & 0.0046 & 0.399 \\
\hline & Year & 0.0035 & 0.437 \\
\hline \multirow[t]{5}{*}{ 1981-2008 } & Winter & 0.0497 & 0.231 \\
\hline & Spring & 0.0637 & 0.060 \\
\hline & Summer & 0.0950 & $<0.001$ \\
\hline & Autumn & 0.0389 & 0.126 \\
\hline & Year & 0.0619 & 0.004 \\
\hline \multicolumn{4}{|l|}{ Tmax } \\
\hline \multirow[t]{5}{*}{$1945-1980$} & Winter & -0.0031 & 0.922 \\
\hline & Spring & -0.0505 & 0.099 \\
\hline & Summer & -0.0957 & $<0.001$ \\
\hline & Autumn & -0.1049 & $<0.001$ \\
\hline & Year & -0.0635 & $<0.001$ \\
\hline \multirow[t]{5}{*}{ 1981-2008 } & Winter & 0.0322 & 0.478 \\
\hline & Spring & 0.0421 & 0.340 \\
\hline & Summer & 0.1157 & $<0.001$ \\
\hline & Autumn & 0.0899 & 0.028 \\
\hline & Year & 0.0701 & 0.012 \\
\hline \multicolumn{4}{|l|}{ Tmin } \\
\hline \multirow[t]{5}{*}{ 1945-1980 } & Winter & 0.0320 & 0.335 \\
\hline & Spring & 0.0228 & 0.267 \\
\hline & Summer & -0.0060 & 0.631 \\
\hline & Autumn & 0.0371 & 0.046 \\
\hline & Year & 0.0213 & 0.068 \\
\hline \multirow[t]{5}{*}{ 1981-2008 } & Winter & 0.0835 & 0.086 \\
\hline & Spring & 0.0756 & 0.038 \\
\hline & Summer & 0.0700 & $<0.001$ \\
\hline & Autumn & 0.0606 & 0.012 \\
\hline & Year & 0.0724 & 0.003 \\
\hline
\end{tabular}

\subsection{Change in extreme events}

Meehl et al. (2000a) noted that the frequency of extremes changes nonlinearly with a change in the means, and a small change in the mean can result in a large change in the frequency of extremes. In turn, a change in the variance would have a larger effect on the frequency of extremes than would a change in the mean. This becomes more complicated when the mean, variance and even the form of distribution are all changing simultaneously, affecting the occurrence of extremes in different ways. In the case of a long observation period, trends can describe the alteration of all statistics of an initial distribution, often specified as a normal Gaussian. For example, some authors (Schär \& Jendritsky 2004, Schär et al. 2004) have attempted to explain the very high summer temperatures in western Europe in 2003 by an increase in the variance of the Gaussian model. In their analysis, the trend in extremes was implicitly explained by the trend in the central part of a distribution.

All temperature series in this research were initially tested for normality (Corobov \& Overcenco 2010). For Tmean some negative skewness and positive kurtosis were observed only in autumn. Small positive skewness and kurtosis were inherent in the distribution of spring minimum temperatures. In all other cases a good normal distribution fit is observed, and most tests suggest that seasonal and annual averages come from a normal distribution. The results also indicate that in spring and summer all temperature variables (except Tmean in spring) have tendencies to positive skewness and kurtosis; in autumn and winter, negative values predominate. The normal distribution of the seasonal temperature averages facilitates the analysis of extremes. When temperatures are distributed normally a nonstationary distribution implies changes in means or variances. Usually, increases in Tmean will lead to increases in record hot weather. Based on Tmean records from 17 climate stations spread around the globe, Benestad (2004) showed that by the end of the 20th century the number of record temperatures was higher than expected if the series had been stationary.

In our study the means and extremes of seasonal maximum and minimum temperatures have been analyzed to assess whether significant changes emerged over recent decades, and whether there is a relationship between mean values and the upper extreme values defined by the 90th and 95th percentiles. Because variances of maximum and minimum temperatures in the 2 periods, 1945-1980 and 1981-2008, were not found to be statistically different (except for annual minima, Table 3), the threshold values are defined similarly over the whole observation period. For each of the 2 subperiods we selected seasonal averages of Tmax and Tmin, the averages of absolute maxima and minima, as well as the number of years with values in excess of a selected threshold (Table 4). Since the duration of the periods are different, the total numbers of exceedance were transformed into frequency per decade.

Several findings were noted. The change in frequency and intensity of air temperature extremes differed for maximum and minimum temperatures. There was a lack of significant differences between Tmax values for the 2 periods (Table 3 ), which corresponded 
Table 2. Comparison of mean air temperature (Tmean) variables in 1887-1980 (subscript 1) and 1981-2008 (subscript 2) at Chisinau weather station. Mean values $\left(\bar{X}^{\circ}{ }^{\circ} \mathrm{C}\right)$ are compared using a t-test, standard deviations $\left(\mathrm{SD},{ }^{\circ} \mathrm{C}\right)$ using an F-test, and distributions using a Kolmogorov-Smirnov (K-S) test. Dn: maximum distance between 2 cumulative distributions

\begin{tabular}{|lrccccccc|}
\hline & \multicolumn{3}{c}{ Mean } & \multicolumn{3}{c}{ SD } & \multicolumn{3}{c|}{ K-S test } \\
& $\bar{x}_{1}$ & $\bar{x}_{2}$ & $\mathrm{p}$ & $\sigma_{1}$ & $\sigma_{2}$ & $\mathrm{p}$ & $\mathrm{Dn}$ & $\mathrm{p}$ \\
\hline Winter & -2.15 & -1.06 & 0.012 & 2.05 & 1.75 & 0.343 & 0.288 & 0.058 \\
Spring & 9.39 & 10.10 & 0.019 & 1.35 & 1.46 & 0.584 & 0.320 & 0.025 \\
Summer & 20.47 & 21.11 & 0.008 & 1.07 & 1.16 & 0.563 & 0.276 & 0.077 \\
Autumn & 9.98 & 10.26 & 0.325 & 1.41 & 1.08 & 0.122 & 0.181 & 0.498 \\
Year & 9.42 & $10.10<0.001$ & 0.78 & 0.96 & 0.158 & 0.378 & 0.005 \\
\hline
\end{tabular}

Table 3. As for Table 2, except that $\bar{x}_{1}$ represents $1945-1980$, and mean maximum and minimum temperatures (Tmax and Tmin, respectively) are included

\begin{tabular}{|c|c|c|c|c|c|c|c|c|}
\hline & \multicolumn{3}{|c|}{ Mean } & \multicolumn{3}{|c|}{$\mathrm{SD}$} & \multicolumn{2}{|c|}{$\mathrm{K}-\mathrm{S}$ test } \\
\hline & $\bar{x}_{1}$ & $\bar{x}_{2}$ & $\mathrm{p}$ & $\sigma_{1}$ & $\sigma_{2}$ & $\mathrm{p}$ & Dn & $\mathrm{p}$ \\
\hline \multicolumn{9}{|l|}{ Tmean } \\
\hline Winter & -1.63 & -1.06 & 0.257 & 2.13 & 1.75 & 0.290 & 0.186 & 0.657 \\
\hline Spring & 9.61 & 10.09 & 0.195 & 1.48 & 1.46 & 0.926 & 0.293 & 0.139 \\
\hline Summer & 20.69 & 21.11 & 0.147 & 1.12 & 1.16 & 0.836 & 0.271 & 0.202 \\
\hline Autumn & 10.12 & 10.26 & 0.594 & 1.05 & 1.08 & 0.858 & 0.200 & 0.562 \\
\hline Year & 9.69 & 10.10 & 0.069 & 0.78 & 0.96 & 0.256 & 0.329 & 0.069 \\
\hline \multicolumn{9}{|l|}{ Tmax } \\
\hline Winter & 1.35 & 1.54 & 0.694 & 1.93 & 1.89 & 0.931 & 0.099 & 0.998 \\
\hline Spring & 15.05 & 14.75 & 0.532 & 1.91 & 1.85 & 0.882 & 0.127 & 0.961 \\
\hline Summer & 26.42 & 26.40 & 0.955 & 1.80 & 1.37 & 0.144 & 0.159 & 0.822 \\
\hline Autumn & 14.42 & 13.59 & 0.077 & 1.88 & 1.78 & 0.779 & 0.218 & 0.448 \\
\hline Year & 14.31 & 14.07 & 0.393 & 1.00 & 1.23 & 0.239 & 0.238 & 0.336 \\
\hline \multicolumn{9}{|l|}{ Tmin } \\
\hline Winter & -4.59 & -3.37 & 0.021 & 2.04 & 2.08 & 0.906 & 0.294 & 0.132 \\
\hline Spring & 5.10 & 6.25 & 0.002 & 1.27 & 1.58 & 0.214 & 0.464 & 0.002 \\
\hline Summer & 15.17 & 16.49 & $<0.001$ & 0.77 & 0.86 & 0.505 & 0.635 & $<0.001$ \\
\hline Autumn & 5.93 & 6.81 & 0.003 & 1.17 & 1.07 & 0.629 & 0.401 & 0.013 \\
\hline Year & 5.40 & 6.54 & $<0.001$ & 0.73 & 1.11 & 0.022 & 0.575 & $<0.001$ \\
\hline
\end{tabular}

times in summer and autumn, and 3 times for the annual temperatures.

Based on the trend in summer Tmax, Beniston \& Stephenson (2004) showed that higher-order statistics (variance, skewness and kurtosis) are uncorrelated with average statistics, implying a symmetric shift in the Probability Density Function (PDF), in which the mean changes but the shape of the distribution does not. However, this is not necessarily the case elsewhere, in particular for Chisinau, a change in the shape of distribution-especially for Tmin - also occurs (Fig. 5).

\subsection{The summer of 2007 in the context of Moldova's changing climate}

The hot summer of 2003 in western Europe is well known and well studied; it was even documented as a special case study in the IPCC AR4 (Parry et al. 2007). However, there was a second, much less well-known, hot summer that was observed in 2007 and affected most of southern and southeastern Europe. In particular, this year was among the hottest summers in Romania over the entire observational period 1901-2007 (Busuioc et al. 2007); it also was the warmest in the history of instrumental observations in Moldova, when practically all temperature records were broken in winter, spring and especially in summer (Bugaeva \&

with no difference in the number of extremes occurring in winter and summer, and a small increase in annual extremes of Tmax (Table 4). For extreme absolute maxima, an increase was observed in winter and for annual exceedance of the 90th percentile threshold $\left(\mathrm{P}_{90}\right)$.

In contrast, many more significant changes were observed in the Tmin distributions, supporting the above conclusion that the general warming in Chisinau was primarily associated with the increase in minimum temperatures. Here, the statistically significant change in summer and annual distributions (Table 3) has resulted in more frequent extreme events. In particular, in the 1940s-1970s almost no one seasonal or annual Tmin value was higher than the 90th percentile, but it was exceeded 6 times (winter) and 7 times (summer and annual) after 1980 . The 95th percentile was exceeded 5
Mironova 2007). The research of Busuioc et al. (2007) showed that a persistent anticyclonic structure over the region associated with very large positive temperature anomalies at $850 \mathrm{hPa}$, were the main reasons for the very hot summer of 2007 . Similar to 2003 in western Europe, 2007 seemed unusual for the historical climate of the country and may have been, using the figurative expression of Beniston (2004), 'a shape of things to come'. Therefore, it is of interest to consider the hot temperatures of 2007 in the context of temperature extremes in Moldova, to address how unusual the summer of 2007 was and to estimate the return period also considered as 'expected frequency', of such an extreme year. Summer Tmean in Chisinau in 2007 is compared with the distribution of a baseline climate for 1961-1990 in Fig. 6. Monthly Tmean ranged from 2.5 to $4.0 \sigma$ over the baseline climate and the summer 
Table 4. Occurrence of extreme mean and absolute maximum and minimum seasonal temperatures (total number / number per decade) above different temperature thresholds in Chisinau during 2 periods of observation. $T$ : temperature average; mean: mean of daily maximum/minimum temperatures; mean of absolute values: mean of seasonal absolute maxima/minima for the observation period; $\mathrm{P}_{90}$ and $\mathrm{P}_{95}$ : 90th and 95th percentiles, respectively, considered as excess threshold temperatures

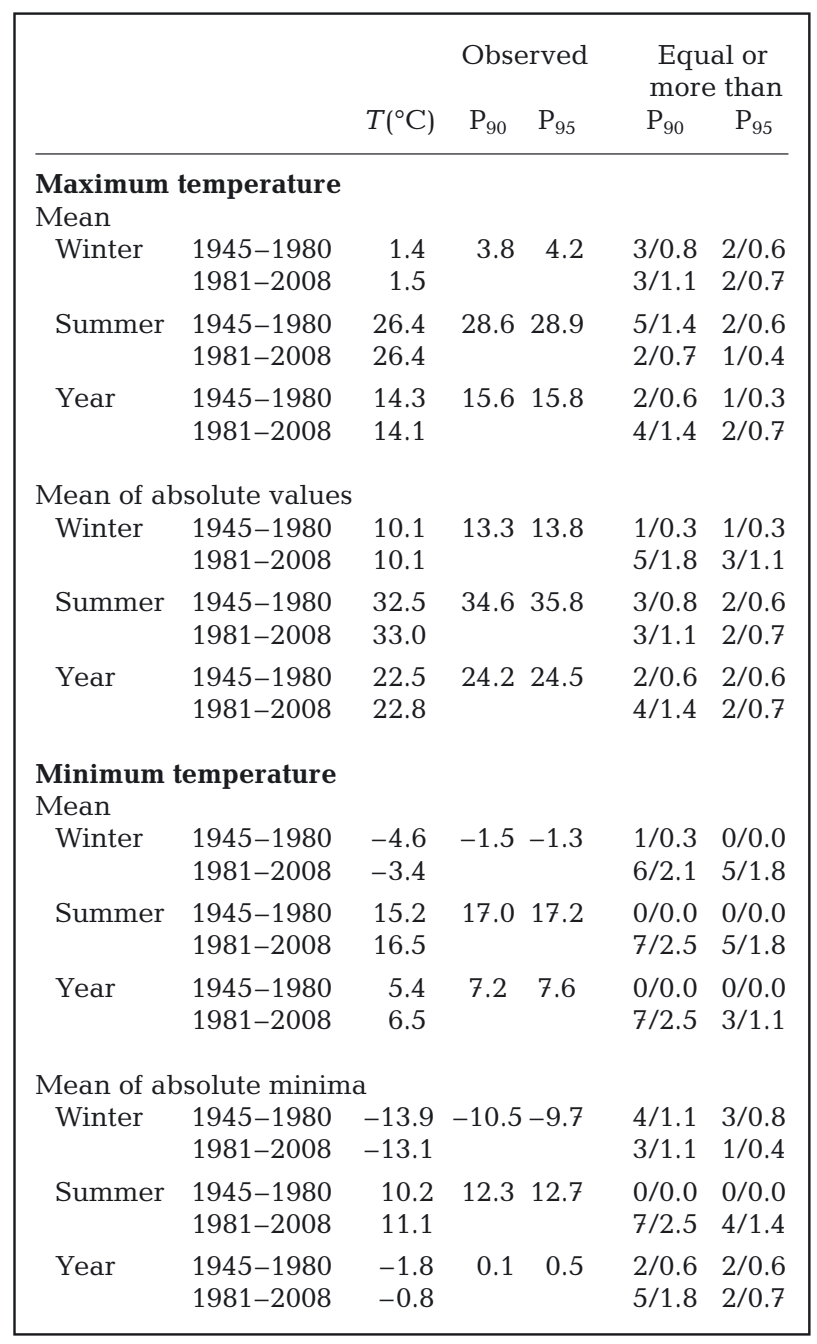

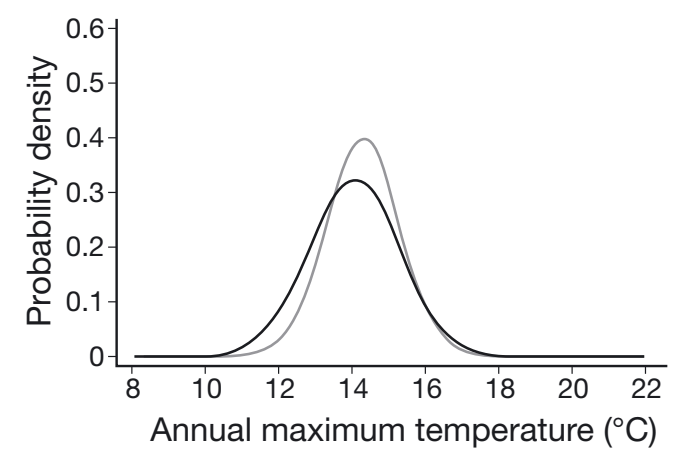

Tmean was $5 \sigma$ above the baseline, or considerably more to the right of its 'reference' distributions.

As evident from Table 5, summer temperatures similar to those in 2007 were extremely unlikely in the baseline climate. Analogous July Tmeans were expected about once in $10000 \mathrm{yr}$, July Tmax once in $2000 \mathrm{yr}$, and July Tmin once in $300 \mathrm{yr}$. The return periods for June and August temperatures are somewhat shorter, but also in the order of 100-1000 yr. However, such a hot summer is much more likely when compared with the climate of the last 2 decades; in this case the summer of 2007 would have a return period of $100 \mathrm{yr}$ for summer Tmean and Tmax, and $30 \mathrm{yr}$ for Tmin. The recurrence of the monthly temperatures of 2007 is probably once per decade to century.

\section{CONCLUSIONS}

The analysis of the observed trends in Chisinau air temperatures over the last 120 yr provides an opportunity to identify evidence of clear change in the air temperature regime of Moldova that can be summarized as follows.

- The acceleration of anthropogenic climate change in the last 3 decades is clearly displayed on a regional level through changed temperature trends and extreme events.

- The regional climate of Moldova is significantly changing. Beginning in the early 1980s, the trends of air temperature observed at Chisinau weather station have changed sharply both by their direction and rate.

- The general positive trend in temperature for the entire period of instrumental observation is mainly caused by warming in the last 3 decades, and given changes in the distribution of temperatures, a new baseline climate is being observed.

- There is a certain asymmetry between the change in the Tmax and Tmin. While differences between seasonal distributions of maximum temperatures in the

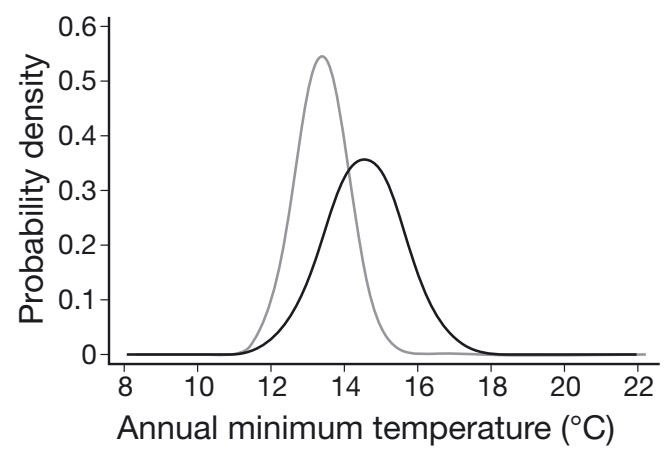

Fig. 5. Probability density functions of mean annual maximum and minimum temperatures for 2 observation periods (grey: 1945-1980, black: 1981-2008); for the corresponding values of mean and $\sigma$ (standard deviation), see Table 3 
current climate compared with the 1940s-1970s are largely non-significant, the minimum temperatures have changed significantly in their mean values and distribution. Thus, recent regional warming is caused mainly by an increase of minimum (night) temperatures.
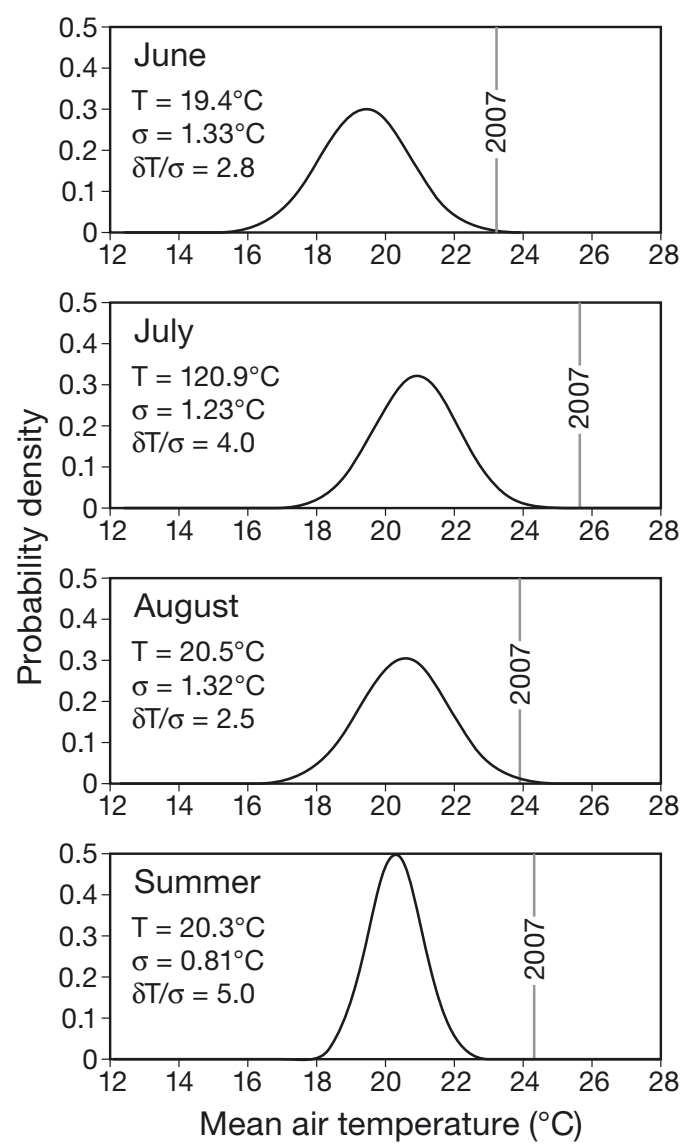

Fig. 6. Mean monthly and summer air temperature in Chisinau in 2007 (vertical lines) relative to the temperatures of the $30 \mathrm{yr}$ baseline period (1961-1990) approximated by a normal distribution curve. T: observed temperatures; $\sigma$ : SD of the baseline period; $\delta \mathrm{T} / \sigma$ normalised anomalies from baseline norms

Table 5 . The probability of air temperatures observed in summer 2007 for the Chisinau baseline (1961-1990) and recent climates (1991-2008)

\begin{tabular}{|lrrr|}
\hline & $T$ mean & $T \max$ & \multicolumn{1}{c|}{$T$ min } \\
\hline 1961-1990 & & & \\
June & 0.00540 & 0.01735 & 0.00594 \\
July & 0.00012 & 0.00046 & 0.00323 \\
August & 0.01184 & 0.05363 & 0.00161 \\
Summer & $<0.00001$ & 0.00020 & $<0.00001$ \\
1991-2008 & & & \\
June & 0.02553 & 0.02709 & 0.04474 \\
July & 0.02851 & 0.01110 & 0.11357 \\
August & 0.11863 & 0.13365 & 0.06853 \\
Summer & 0.01160 & 0.01095 & 0.03138 \\
\hline
\end{tabular}

- As a result, the change in frequency and intensity of temperature extremes differs between maximum and minimum temperatures. There is no increase in the number of winter and summer maximum extremes against a sharp increase in the frequency of summer and annual extreme minimum temperatures.

- The record hot summer of 2007 was unusual for the baseline climate of Chisinau and based on the Chisinau temperature regime during the middle of the 20th century would have been deemed pratically impossible.

Acknowledgements. The research described in this publication was made possible in part by Award No. MOB-2928-CS08 of the U.S. Civilian Research and Development Foundation for the Independent States of the Former Soviet Union (CRDF). Any opinions, finding and conclusions or recommendations expressed in this material are those of the authors and do not necessary reflect those of the CRDF. Professor Tim Sparks and anonymous reviewers are acknowledged for their useful comments.

\section{LITERATURE CITED}

Adger WN, Arnell NW, Tompkins EL (2005) Successful adaptation to climate change across scales. Glob Environ Change 15:77-86

Albert MG, Tank K, Zwiers FW and Zhang X (2009) Guidelines on analysis of extremes in a changing climate in support of informed decisions for adaptation WMO-TD No. 1500. World Meteorological Organization, Geneva

$>$ Benestad RE (2003) How often can we expect a record event? Clim Res 25:3-13

> Benestad RE (2004) Record-values, nonstationarity tests and extreme value distributions. Global Planet Change 44:11-26

Beniston M (2004) The 2003 heat wave in Europe: a shape of things to come? An analysis based on Swiss climatological data and model simulations. Geophys Res Lett 31:L02202. doi:10.1029/2003GL018857

Beniston M, Stephenson DB (2004) Extreme climatic events and their evolution under changing climatic conditions. Global Planet Change 44:1-9

Beniston M, Stephenson DB, Christensen OB, Ferro CAT and others (2007) Future extreme events in European climate: an exploration of regional climate model projections. Clim Change 81:71-95

Bugaeva T, Mironova T (2007) Characteristics of meteorological and climatological conditions in Moldova in summer of 2007 (in Moldavian). www.meteo.md/newsait/vara07. htm (accessed 20 May 2010)

Busuioc A, Dumitrescu A, Soare E, Orzan A (2007) Summer anomalies in 2007 in the context of extremely hot and dry summers in Romania. Roman J Meteorol 9:1-17

Caprio JM, Quamme HA, Redmon KT (2009) A statistical procedure to determine recent climate change of extreme daily meteorological data as applied at two locations in Northwestern North America. Clim Change 92:65-81

Carter TR, Jones RN, Lu X, Bhadwal S and others (2007) New assessment methods and the characterisation of future conditions. In: Parry ML, Canziani OF, Palutikof JP, van der Linden PJ, Hanson CE (eds) Climate change 2007: impacts, adaptation and vulnerability. Contribution of Working Group II to the Fourth Assessment Report of the 
Intergovernmental Panel on Climate Change. Cambridge University Press, Cambridge, p 133-171

Coles S (2001) An introduction to statistical modeling of extreme values. Springer-Verlag, London

Corobov R (2008) Regional climate and environmental change: Moldova case study. In: Groisman PYa, Ivanov SV (eds) Regional aspects of climate-terrestrial-hydrologic interactions in non-boreal Eastern Europe. NATO Science Series C: Environmental Security, Springer, Dordrecht, p 79-86

Corobov R, Overcenco A (2010) To normality of air temperature distribution with an emphasis on extremes. In: Academician Eugene Fiodorov - 100 years. Collection of scientific articles. Eco-TIRAS, Bendery, p 35-41

Gil-Alana LA (2008) Time trend estimation with breaks in temperature time series. Clim Change 89:325-337

Good P, Bärring L, Giannakopoulos C, Holt T, Palutikof J (2006) Non-linear regional relationships between climate extremes and annual mean temperatures in model projections for 1961-2099 over Europe. Clim Res 31:19-34

Goscommet USSR (1990) Scientific and applied reference book on USSR climate. Series 3: long-term data. Parts 1-3, issue 11: Moldavian SSR. Gidrometeoizdat, Leningrad (in Russian)

Groisman PY, Ivanov SV (eds) (2008) Regional aspects of climate-terrestrial-hydrologic interactions in non-boreal Eastern Europe. NATO Science Series C: environmental security. Springer, Dordrecht

Hanson CE, Palutikof JP, Perry AH (eds) (2006) MICE: modelling the impact of climate extremes. Clim Res 31

Hanson CE, Palutikof JP, Livermore MTJ, Bärring L and others (2007) Modelling the impact of climate extremes: an overview of the MICE project. Clim Change 81:163-177

IPCC (Intergovernmental Panel on Climate Change) (2007a) Summary for policymakers. In: Solomon S, Qin D, Manning M, Chen Z, Marquis M, Averyt KB, Tignor M, Miller HL (eds) Climate change 2007: the physical science basis. Contribution of Working Group I to the Fourth Assessment Report of the Intergovernmental Panel on Climate Change. Cambridge University Press, Cambridge, p 1-18

IPCC (Intergovernmental Panel on Climate Change) (2007b) Parry ML, Canziani OF, Palutikof JP, van der Linden PJ, Hanson CE (eds) Climate change 2007: impacts, adaptation and vulnerability. Contribution of Working Group II to the Fourth Assessment Report of the Intergovernmental Panel on Climate Change. Cambridge University Press, Cambridge

Jones PD, Parker DE, Osborn TJ, Briffa KR (2009) Global and hemispheric temperature anomalies - land and marine instrumental records. In: Trends: a compendium of data on global change. US Department of Energy, Oak Ridge
National Laboratory, Carbon Dioxide Information Analysis Center, Oak Ridge, TN. doi:10.3334/CDIAC/cli.002

Lu A, He Y, Zhang Z, Pang H, Gu J (2004) Regional structure of global warming across China during the twentieth century. Clim Res 27:189-195

- Meehl GA, Karl T, Easterling DR, Changnon S and others (2000a) An introduction to trends in extreme weather and climate projections: observations, socioeconomic impacts and model projections. Bull Am Meteorol Soc 81:413-416

Meehl GA, Zwiers F, Evans J, Knutson T, Mearns L, Whetton $P(2000 b)$ Trends in extreme weather and climate events: issues related to modeling extremes in projection of future climate change projections. Bull Am Meteorol Soc 81: 427-436

Parey S, Malek F, Laurent C, Dacunha-Castelle D (2007) Trends and climate evolution: statistical approach for very high temperatures in France. Clim Change 81:331-352

Parry ML, Canziani OF, Palutikof JP, van der Linden PJ, Hanson CE (eds) (2007) Cross-chapter case study. In: Climate change 2007: impacts, adaptation and vulnerability. Contribution of Working Group II to the Fourth Assessment Report of the Intergovernmental Panel on Climate Change, Cambridge University Press, Cambridge, p 843-868

Schär C, Jendritsky G (2004) Hot news from summer 2003. Nature 432:559-569

Schär C, Vidale PL, Lüthi D, Frei C, Hüberli C, Liniger MA, Appenzeller C (2004) The role of increasing temperature variability in European summer heatwaves. Nature 427: 332-336

Semenov MA (2008) Simulation of extreme weather events by a stochastic weather generator. Clim Res 35:203-212

> Sillmann J, Roeckner E (2008) Indices for extreme events in projections of anthropogenic climate change. Clim Change 86:83-104

Statgraphics (2009) Statgraphics Centurion XVI user manual. StatPoint Technologies, Warrenton, VA

Suarez R (2009) Improving modeling of extreme events using generalized extreme value distribution or generalized pareto distribution with mixing unconditional disturbances. Munich Personal RePEc Archive Paper No. 17482 (unpubl.). Munich University Library, Munich. mpra.ub. uni-muenchen.de/17482/ (accessed: 10 November 2009)

> Tebaldi C, Haynoe K, Arblaster JM, Meehl GA (2006) Going to the extremes: an intercomparison of model-simulated historical and future changes in extreme events. Clim Change 79:185-211

> Therivel R, Ross B (2007) Cumulative effects assessment: Does scale matter? Environ Impact Assess Rev 27:365-385

Unkaśević M, Vujović D, Tośić I (2005) Trends in extreme summer temperatures at Belgrade. Theor Appl Climatol 82:199-205

Appendix 1. Definition and explanation of STARDEX and MICE

STARDEX (Statistical and regional dynamical downscaling of extremes for European regions) is a part of the cooperative cluster of projects exploring future changes in extreme events in response to global warming. See: www.ist-orld.org/Project Details.aspx? ProjectId=732460bb44d34626a495d23203 c7e9d4; http://regclim.met.no/wrkshop-2005-10/Goodess_sl_ workshop.pdf
MICE (Modelling the Impact of Climate Extremes) examines the impact of climate extremes, initially aiming at identifying and cataloguing extremes in observed and modelled climate data, as well as at assessing their future changes and the impact of these changes on specified economic sectors (Hanson et al. 2006, 2007) 